\title{
Attitude of Headmasters and Teachers towards the Right to Education Act (2009), India
}

\author{
Srikanta Mandal ${ }^{1} \&$ Pranab Barman ${ }^{2}$ \\ ${ }^{I}$ (Research Scholar; Dept. of Education; Sidho-Kanho-Birsha University, Purulia, West Bengal, India) \\ ${ }^{2}$ (Assistant Professor; Dept.of Education; Sidho-Kanho-Birsha University, Purulia, West Bengal, India)
}

\begin{abstract}
In the present study an attempt has been made by the investigators to study the attitude of secondary school Headmasters and Teachers towards the "Right to Education Act, 2009 or RTE Act, 2009" in the district of Purulia, West Bengal. The investigators have used Descriptive Survey method for the present study. The sample consists of 30 Headmasters and 150 Teachers from 30 (Thirty) selected secondary schools which are situated in the district of Purulia, West Bengal. The Purposive sampling technique has been used for the selection of sample. The investigators have developed two Questionnaires (One for Headmasters and another for Teachers) by themselves to measure the attitude of Headmasters and Teachers towards the Right to Education Act, 2009. For the analysis of data Mean, S.D and 't' test have been used in the present study. The overall results indicate that the attitude of secondary school Headmasters of the district of Purulia is neither Favorable nor Unfavorable i.e. Moderate towards the Right to Education Act, 2009. But on the other side, it is found that the secondary school Teachers of the district of Purulia are possessed Favorable attitude towards the Right to Education Act, 2009. Therefore, it can be said that there is a significant difference between Headmasters and Teachers regarding their attitude towards the Right to Education Act, 2009. It is reflected through the present study that the Secondary School Teachers have more favorable attitude than that of the Headmasters about the various aspects enshrined in the Right to Education Act, 2009, India.
\end{abstract}

Keywords: Attitude, Headmasters, Teachers, Right to Education, RTE Act (2009), Basic Provisions in the RTE Act.

\section{Introduction}

India is a largest democratic country in this world with the 1.21 crores people (Census Report of India, 2011). But one of the major problems of this country is that $42.1 \%$ of people are suffering from inequality in education here (United Nations Development Programme - UNDP, 2014). For this reason, the position of India (India's HDI Rank-135) is too behind than the other developed countries like, U.S.A., Japan, and China in respect to Human Development Index (HDI) (UNDP, 2010). After 68 years of independence, India is not able to provide minimum level of education to its all citizen till now. According to the Indian Census Report (2011), only $74.04 \%$ people are literate in India. It means that almost $25.96 \%$ people are illiterate in our country India still now. In this background, the Right to Education Act (2009) has taken by the Indian Government is a historical and significant initiative which already begins to give pace in the Indian education system since April $1,2010$.

\section{Historical Background of the RTE Act (2009):}

After independence, Article 45 under the newly framed Constitution stated that the state shall endeavour to provide free and compulsory education to all children until they complete the age of fourteen years within a period of ten years from the commencement of this Constitution. 86 ${ }^{\text {th }}$ Amendment Act (2000) via Article 21 A (Part III) seeks to make free and compulsory education a Fundamental Right for all children in the age group 6-14 years. The amendment also introduced a new article $21 \mathrm{~A}$, which imposes a duty on parents and guardians to provide their children with educational opportunities. In October, 2003 a first draft of the legislation envisaged in the above Article, viz., Free and Compulsory Education for Children Bill, 2003, was prepared and posted on this website in October, 2003, inviting comments and suggestions from the public at large. In 2004, subsequently, taking into account the suggestions received on this draft, a revised draft of the Bill entitled Free and Compulsory Education Bill, 2004, was prepared. In June, 2005, the CABE (Central Advisory Board of Education) committee drafted the 'Right to Education' Bill and submitted to the Ministry of HRD. MHRD sent it to National Advisory Committee (NAC) where Mrs. Sonia Gandhi is the Chairperson. The National Advisory Committee (NAC) sent the bill to Prime Minister of India for his observation. The finance committee and planning commission rejected the Bill citing the lack of funds and model bill was to states for making necessary arrangements (Post- $86^{\text {th }}$ amendment, States had already cited lack of funds at State level). 
This was revised and became an Act in August, 2009 but was not notified for roughly 7 months. The Right of Children to Free and Compulsory Education Act came into force from April 1, 2010. This was a historic day for the people of India as from that day the Right to education will be accorded the same legal status as the right to life as provided by Article 21A of the Indian Constitution. Every child in the age group of 6-14 years will be provided 8 years of elementary education in an age appropriate classroom in the vicinity of his/her neighbourhood. For the first time in the history of India it is made a right enforceable by pitting in Chapter 3 of the Constitution as Article 21. This entitles children to have the right to education enforced as a fundamental right. Now every child between the ages of 6 to 14 years has the right to free and compulsory education. This is stated as per the $86^{\text {th }}$ Constitution Amendment Act added Article 21A. The government schools shall provide free education to all the children and the schools will be managed by school management committees (SMC). Private schools shall admit at least $25 \%$ of the children in their schools without any fee. 'Free' means as removal of any financial barrier by the state that prevents a child from completing eight years of schooling. 'Compulsory' means compulsory admission, attendance and completion of elementary education. 'Compulsion' means as compulsion on the state/ local bodies, rather than targeting parents, fundamental duty of parents to send their children to schools.

\section{Basic Provisions made in the RTE Act (2009):}

In 2009, Indian Government has adopted the 'Right to Education Act' to ensure the Free and Compulsory Elementary Education for every child between the age group of 6-14 years by mentioning so many basic provisions. Few important basic provisions of the RTE Act (2009) has mentioned below:

1. It is included in the fundamental rights of Indian constitution in Article $21 \mathrm{~A}$ inserted by the $86^{\text {th }}$ Amendment in December, 2002. The provisions of the Act came into force from $1^{\text {st }}$ April, 2010.

2. The name of the Act is "The Right of Children to Free and Compulsory Education Act, 2009".

3. It shall extend to the whole of India except the State of Jammu \& Kashmir.

4. It is an Act to provide for free and compulsory education to all children of the age of 6-14 years i.e. from Class I to VIII.

5. It shall be the duty of every parents or guardian to admit or cause to be admitted his or her child or ward to an elementary education in the neighbourhood school.

6. Both the Central and State Government will share the financial and other responsibilities.

7. The local authority like, Municipal Corporation, Municipal Council, Zilla Parishad or Nagar Panchayat or Panchayat maintain records of children up to the age of fourteen years residing within its jurisdiction and ensure admission, attendance and completion of elementary education by every child.

8. The local authority shall ensure admission of children of migrant families.

9. No capitation fee and screening procedure for admission in elementary classes and no child shall be denied admission if he or she is entitled to take admission according to the provision of the Act.

10. The private school managements have to take at least $25 \%$ of the class strength should belong to the economically weaker sections (EWS) in the neighbourhood at the time of admission in Class-I and provide free and compulsory elementary education till its completion.

11. No child admitted in a school shall be held back in any class or expelled from school till the completion of elementary education.

12. No child shall be subjected to physical punishment or mental harassment.

13. A teacher shall maintain regularity and punctuality in attending the school and complete curriculum within the specified time.

14. The pupil teacher ratio from class I to V shall be 30:1 and from class VI to VIII shall be 35:1.

15. Teacher vacancy in a school shall not exceed 10 percent.

16. No teacher shall be deployed for any non-educational purpose either than the decennial population census duties relating to disaster relief and general election in different purpose.

17. No teacher shall engage himself or herself in private tuition or private teaching activity.

18. No child shall be required to pass any Board examination till completion of elementary education.

19. Minimum numbers of working days/instructional hours in an academic year shall be: 200 working days for Class I to V or 800 instructional hours and 200 working days or 1000 instructional hours for Class VI to VIII.

20. Minimum number of working hours per week for the teachers shall be 45 (forty five) including preparation hours.

21. There shall be a library in each school providing newspapers, magazines and books on all subjects including story books.

22. Play material, games and sports equipment shall be provided to each class as required.

23. National level test shall be conducted like Teacher Eligibility Test (TET) for making eligible the teacher to teach in elementary classes and maintaining quality in elementary education. 


\section{Review of Related Literature}

Shruti Kant Pandey (May, 2013) has conducted a study on "An exploratory study on the apprehensions and implementation of Right to Education Act, 2009" to detect the underlying get-outs of the Right of Children to Free and Compulsory Education Act, 2009 popularly known as the RTE Act, 2009. In the light of above facts and discussion thereon it is evident that RTE, 2009 is a unique document as far provisions and norms are concerned. It can bring drastic changes in the state of elementary education in our country. But poor implementation, slackness on the part of several governments and their departments, as well as discontent of few fractions of our society are hampering proper progress on the implementation of the RTE Act, 2009. If these hindrances are embarked upon immediately; RTE Act, 2009 can bring unimaginable results and be an exceptional instrument in making India a knowledge superpower by 2020.

Sarika Malik \& et al. (2013) have conducted a study on "Awareness of Right to Education Act among Prospective Teachers" to find out the level of awareness of rural and urban prospective teachers about Right to Education. The findings of the study reveal that the urban and rural prospective teachers' ratio is high; there is necessity to develop the awareness towards RTE, which in turn helps them to develop the same among their students.

Ajay. M. Gadam (2013) has conducted a study on "Teacher Awareness of the Responsibility under Right to Free and Compulsory Education Act" to study the impact of working experience of teacher on their awareness of the responsibility under right to free and compulsory education act and to study the impact of educational qualification of teachers on awareness of the responsibility. The findings of the study reveal that there is significant impact of teacher's working experience on their awareness of the responsibility under RTE Act, 2009. Those teacher's working experience is high his/her awareness of the responsibility under the Right to Free and Compulsory Education Act is high and those teacher's working experience is low his/her awareness of the responsibility under the Right to Free and Compulsory Education Act is low. And there is significant impact of the educational qualification of the teacher on their awareness of the responsibility under RTE Act, 2009. Those teacher's educational qualification is high his/her awareness of the responsibility under Right to Free and Compulsory Education Act is high and those teacher's educational qualification is low his/her awareness of the responsibility under Right to Free and Compulsory Education Act is low.

Fathima Jaseena (2011) has conducted a study on "Right to Education-A Study on the Awareness of M.Ed Trainees" to find out the awareness of M.Ed students about right to education and to study the effect of gender and type of management of the institution on the awareness of Right to Education Act, 2009. The findings of the study reveal that male M.Ed students possess significantly higher awareness about the Right to Education Act, 2009 than the female M.Ed students. And the management of the M.Ed College does not effect on the awareness of the Right to Education Act, 2009.

Niradhar Dey \& Binod Beck (2011) have conducted a study on "The Right of Children to Free and Compulsory Education Act 2009: Teachers Perception" to study the awareness and opinion of teachers towards the Right of Children to Free and Compulsory Education Act, 2009. The findings of the study reveal that in most of the cases it was observed that the senior teachers were less aware about the RTE Act, 2009. Senior teachers were not interested to materialize the Act by heart and hand. Though the junior teachers were little bit more ahead than seniors still then it was not impressive and satisfactory. It was also found that most of the teachers were not in favour of prohibition of admission test and fail system in elementary education.

K. Premlakshmi (2011) has conducted a study on "Right to Education and Common School SystemPerception among Teachers" to study the opinion about Common School System from School Teachers of Government and Matriculation Schools. The findings of the study reveal that there is a significant difference in perceptions between male and female teachers towards Common School System. And also found that there is no significant difference in perception between Urban and Rural school teachers towards Common School System.

Dinesh Kumar \& Sarita Sharma (2011) have conducted a study on "A Study of Parents and Teachers Awareness towards Right to Education Act 2009" to assess the level of awareness of teachers and parents of primary to upper primary level students towards the RTE Act, 2009. The findings of the study reveal that the teachers are more significantly aware than that of parents. 


\section{The Present Study}

\section{Need and Significance of the Study:}

1. The present study will help to know the attitude of Headmasters of Secondary Schools towards the RTE Act, 2009 in the district of Purulia, West Bengal.

2. The present study will help to know the attitude of Teachers of Secondary Schools towards the RTE Act, 2009 in the district of Purulia, West Bengal.

3. To conduct this study the present investigators have constructed two Attitude Questionnaires (One for Headmasters and another for Teachers) which will be very helpful for other researchers to conduct future research in the field of Right to Education Act (2009).

4. The findings related to attitude of Headmasters and Teachers will be helpful for the Government and Policy Makers to take some important steps to modify the policies and ideas of Right to Education Act, 2009 for its successful implementation in school education in India.

5. The findings of the present study will also make awareness of the State and Central Government both regarding the Right to Education Act (2009).

\section{Objectives of the Study:}

1. To study the attitude of Secondary School Headmasters towards the Right to Education Act, 2009.

2. To study the attitude of Secondary School Teachers towards the Right to Education Act, 2009.

3. To study the differences between Headmasters and Teachers regarding their attitude towards the Right to Education Act, 2009.

4. To study the differences among Teachers regarding their attitude towards the Right to Education Act, 2009 on the basis of gender.

5. To study the differences among Teachers regarding their attitude towards the Right to Education Act, 2009 on the basis of Streams.

\section{Hypotheses of the Study:}

H0 : There is no high favorable level of attitude of Headmasters towards the Right to Education Act (2009).

$\mathbf{H 0}_{2}$ : There is no high favorable level of attitude of Teachers towards the Right to Education Act (2009).

$\mathbf{H O}_{3}$ : There is no significant difference between Headmasters and Teachers regarding their attitude towards the Right to Education Act (2009).

$\mathbf{H 0}_{4}$ : There is no significant difference between Male and Female Teachers regarding their attitude towards the Right to Education Act (2009).

H0 $_{5}$ : There is no significant difference between Arts and Science Teachers regarding their attitude towards the Right to Education Act (2009).

H0$_{6}$ : There is no significant difference between Arts Male and Arts Female Teachers regarding their attitude towards the Right to Education Act (2009).

$\mathbf{H O}_{7}$ : There is no significant difference between Science Male and Science Female Teachers regarding their attitude towards the Right to Education Act (2009).

H0: : There is no significant difference between Arts Male and Science Male Teachers regarding their attitude towards the Right to Education Act (2009).

H09: There is no significant difference between Arts Female and Science Female Teachers regarding their attitude towards the Right to Education Act (2009).

\section{Definition of the Terms: \\ Attitude:}

Here in this study the investigators have used the term 'Attitude' in the sense that the opinions or views which were reflected by the Secondary School Headmasters and Teachers about the various aspects related to elementary education enshrined in the RTE Act, 2009 in India.

Right to Education Act (RTE Act - 2009):

Here in this study, the investigators have used "The Right to Education Act (2009)" to mean that an Act which was passed by the Indian Government in August, 2009 to ensure the free and compulsory elementary education for every child between the age group of 6-14 years throughout the country.

\section{Headmasters:}

Here in this study, the investigators have used the term 'Headmasters' to mean that those teachers who were serving as a Head of the institution at different Secondary Schools in the district of Purulia, West Bengal.

Teachers:

Here in this study, the investigators have used the term 'Teachers' to mean that those teachers who were serving as an Assistant Teachers at different Secondary Schools in the district of Purulia, West Bengal. 


\section{Methodology of the Study}

\section{Method of the Study:}

The present study is descriptive type in nature. The researcher has used the descriptive type survey method in the present study. Therefore, naturally the investigators have used different tools, techniques, strategies and method of descriptive survey research to collect, analyze and interpret the data.

\section{Population of the Study:}

All Headmasters and Teachers of Secondary Schools in the district of Purulia have been treated as population for the present study.

\section{Sample of the Study:}

The investigators have selected only 30 Headmasters and 150 Teachers from the 10 (Ten) selected secondary schools which are situated in the district of Purulia, West Bengal as sample for the present study.

\section{Sampling Technique:}

The Purposive sampling technique has been used in the selection of the sample.

\section{Tools of the Study:}

The investigators have used two Questionnaires, one for Headmasters and another for Teachers as a tool for collecting the data in the present study. Each Questionnaire consists of 40 items with the combination of positive and negative items. Both Questionnaires have been constructed on the basis of Likert's five point scale i.e. Strongly Agree, Agree, Indifferent, Disagree and Strongly Disagree.

\section{Techniques of Data Analysis:}

The present investigators have used Mean, S.D. and' $t$ '-Test for analyzing the data.

\section{Techniques of Measuring the Level of Attitude:}

After all the items are scored, the scores of all the 40 items are added to obtain the total score of an individual Sample on the Questionnaire. The range of the total score is 40-200 as the Questionnaires are constructed by 40 items on the basis of 5 point Likert Scale. Therefore, the Level of Attitude is considered from Score of the answers and is classified into 5 levels to the Best's Criteria (1977) as follows-

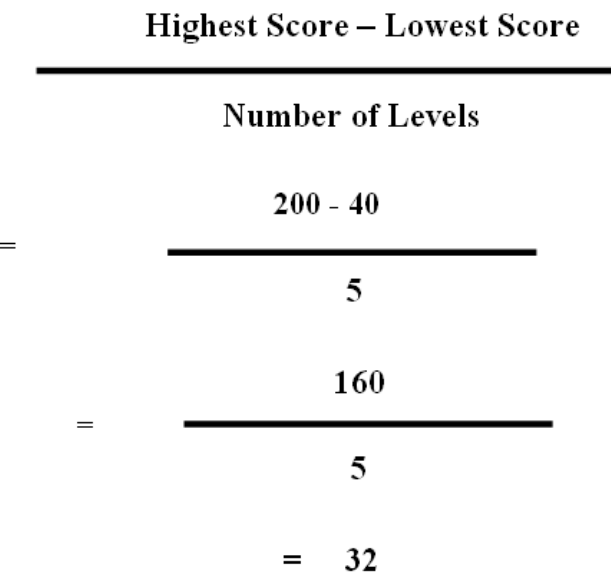

Table No-1

Criteria for Understanding the Means of the Level of Attitude

\begin{tabular}{|c|c|}
\hline Range of Scores & Level of Attitude \\
\hline $40-72$ & Very Unfavorable \\
\hline $73-104$ & Unfavorable \\
\hline $105-136$ & Moderate \\
\hline $137-168$ & Favorable \\
\hline $169-200$ & Very Favorable \\
\hline
\end{tabular}




\section{Results and Discussion}

$\mathrm{HO}_{1}$ : There is no high favorable level of attitude of Headmasters towards the Right to Education Act (2009).

Table No-2

Shows the Number, Mean and S.D of the Total Headmasters

\begin{tabular}{|c|c|c|c|}
\hline Group & Number & Mean & S.D \\
\hline Headmasters & $\mathbf{3 0}$ & $\mathbf{1 3 2 . 5 0}$ & $\mathbf{1 0 . 4 7}$ \\
\hline
\end{tabular}

Note: 40 - 72 = Very Unfavorable, $73-104=$ Unfavorable, $105-136=$ Moderate, $137-168=$ Favorable and 169 - 200 = Very Favorable.

From the table no-2, we can see that the obtained Mean Score of the Headmasters is 132.50 and S.D is 10.47. On the basis of the Best's Criteria, the obtained Mean Score of the Headmasters is 132.50 which fall under the range of Mean Scores of 105-136. It indicates that the level of Attitude of Headmasters fall under the Moderate range group. Therefore, we can say that the level of Attitude of Headmasters of the district of Purulia, West Bengal is at Moderate level. It means that the level of Attitude of secondary school Headmasters of the district of Purulia, West Bengal is neither Favorable nor Unfavorable i.e. Moderate towards the Right to Education Act, 2009.

$\mathrm{HO}_{2}$ : There is no high favorable level of attitude of Teachers towards the Right to Education Act (2009).

Table No-3

Shows the Number, Mean and S.D of the Total Teachers

\begin{tabular}{|c|c|c|c|}
\hline Group & Number & Mean & S.D \\
\hline Teachers & 150 & $\mathbf{1 4 6 . 6 0}$ & 14.74 \\
\hline
\end{tabular}

Note: 40 - 72 = Very Unfavorable, $73-104=$ Unfavorable, $105-136=$ Moderate, $137-168=$ Favorable and 169 - 200 = Very Favorable.

From the table no-3, we can see that the obtained Mean Score of the Teachers is 146.60 and S.D is 14.74. On the basis of the Best's Criteria, the obtained Mean Score of the Teachers is 146.60 which fall under the range of Mean Scores of 137-168. It indicates that the level of Attitude of Teachers fall under the Favorable range group. Therefore, we can say that the level of Attitude of Teachers of the district of Purulia, West Bengal is at Favorable level. It means that the level of Attitude of secondary school Teachers of the district of Purulia, West Bengal is Favorable towards the Right to Education Act, 2009.

H0 $_{3}$ : There is no significant difference between Headmasters and Teachers regarding their attitude towards the Right to Education Act (2009).

Table no-4

Shows the difference between Headmasters and Teachers regarding their attitude towards the Right to Education Act (2009)

\begin{tabular}{|c|c|c|c|c|c|c|c|c|}
\hline Groups & N & Mean & S.D & Mean Difference & S ED & df & $\begin{array}{c}\text { t-value } \\
\text { Significance }\end{array}$ \\
\cline { 1 - 4 } Headmasters & 30 & 132.50 & 10.47 & \multirow{2}{*}{14.1} & 3.52 & 178 & 4.00 & $\begin{array}{c}\text { Significant at } 0.05 \\
\text { level }\end{array}$ \\
\hline Teachers & 150 & 146.60 & 14.74 &
\end{tabular}

From the table no-4, it is observed that the calculated ' $t$ '-value $(' t$ ' $=4.00)$ is greater than the table value at the both 0.01 and 0.05 level of significance ( 2.60 at 0.01 and 1.97 at 0.05 level of significance). Therefore, the result is significant and it indicates that there is significant difference between Headmasters and Teachers regarding their attitude towards the Right to Education Act (2009). Hence, the null hypothesis is rejected. And it means that the attitude of Teachers is more favorable than that of the Headmasters in the district of Purulia, West Bengal towards the Right to Education Act, 2009. 
$\mathrm{HO}_{4}$ : There is no significant difference between Male and Female Teachers regarding their attitude towards the Right to Education Act (2009).

\section{Table no-5}

Shows the difference between Male and Female Teachers regarding their Attitude towards the Right to Education Act (2009)

\begin{tabular}{|c|c|c|c|c|c|c|c|c|}
\hline Groups & N & Mean & S.D & $\begin{array}{c}\text { Mean } \\
\text { Difference }\end{array}$ & S ED $_{\text {t-value }}$ & $\begin{array}{c}\text { Level of } \\
\text { Significance }\end{array}$ \\
\cline { 1 - 5 } Male Teachers & 111 & 145.90 & 14.27 & 2.71 & 3.01 & 148 & 0.90 & Not Significant \\
\cline { 1 - 6 } Female Teachers & 39 & 148.61 & 16.78 &
\end{tabular}

From the table no-5, it is observed that the calculated ' $t$ '-value (' $t$ ' $=0.90)$ is less than the table value at 0.05 level of significance (1.98 at 0.05 level of significance). Therefore, the result is not significant and it indicates that there is no significant difference between the Male and Female teachers regarding their attitude towards the Right to Education Act (2009). Hence, the null hypothesis is accepted.

H05: There is no significant difference between Arts and Science Teachers regarding their attitude towards the Right to Education Act (2009).

Table no-6

Shows the difference between Arts and Science Teachers regarding their attitude towards the Right to Education Act (2009)

\begin{tabular}{|c|c|c|c|c|c|c|c|c|}
\hline Groups & N & Mean & S.D & $\begin{array}{c}\text { Mean } \\
\text { Difference }\end{array}$ & $\mathbf{S}_{\mathrm{ED}}$ & df & t-value & $\begin{array}{c}\text { Level of } \\
\text { Significance }\end{array}$ \\
\cline { 1 - 8 } Arts Teachers & 90 & 146.80 & 14.77 & 0.49 & 2.41 & 148 & 0.20 & Not Significant \\
\cline { 1 - 5 } Science Teachers & 60 & 146.31 & 14.28 & &
\end{tabular}

From the table no-6, it is observed that the calculated ' $t$ '-value (' $t$ ' $=0.20)$ is less than the table value at 0.05 level of significance (1.98 at 0.05 level of significance ). Therefore, the result is not significant and it indicates that there is no significant difference between Arts and Science Teachers regarding their attitude towards the Right to Education Act (2009). Hence, the null hypothesis is accepted.

H06: There is no significant difference between Arts Male and Arts Female Teachers regarding their attitude towards the Right to Education Act (2009).

Table no-7

Shows the difference between Arts Male and Arts Female Teachers regarding their attitude towards the Right to Education Act (2009)

\begin{tabular}{|c|c|c|c|c|c|c|c|c|}
\hline Groups & N & Mean & S.D & $\begin{array}{c}\text { Mean } \\
\text { Difference }\end{array}$ & S & df & t-value & $\begin{array}{c}\text { Level of } \\
\text { Significance }\end{array}$ \\
\hline Arts Male Teachers & 66 & 145.53 & 13.83 & 4.76 & 3.96 & 88 & 1.20 & Not Significant \\
\hline Arts Female Teachers & 24 & 150.29 & 17.56 & & \\
\hline
\end{tabular}

From the table no-7, it is observed that the calculated ' $t$ '-value (' $t$ ' $=1.20)$ is less than the table value at 0.05 level of significance ( 1.98 at 0.05 level of significance ). Therefore, the result is not significant and it indicates that there is no significant difference between Arts Male and Arts Female Teachers regarding their attitude towards the Right to Education Act (2009). Hence, the null hypothesis is accepted.

$\mathrm{HO}_{7}$ : There is no significant difference between Science Male and Science Female Teachers regarding their attitude towards the Right to Education Act (2009).

\section{Table no-8}

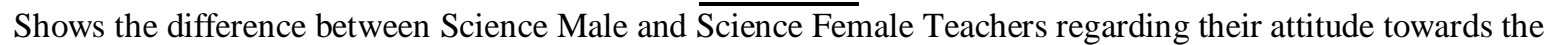
Right to Education Act (2009)

\begin{tabular}{|c|c|c|c|c|c|c|c|c|}
\hline Groups & N & Mean & S.D & $\begin{array}{c}\text { Mean } \\
\text { Difference }\end{array}$ & S ED & df & t-value & $\begin{array}{c}\text { Level of } \\
\text { Significance }\end{array}$ \\
\cline { 1 - 5 } Science Male Teachers & 45 & 146.44 & 13.89 & 0.55 & 4.36 & 58 & 0.11 & Not Significant \\
\hline Science Female Teachers & 15 & 145.93 & 14.89 & & 0.11 \\
\hline
\end{tabular}


From the table no- 8 , it is observed that the calculated ' $t$ '-value (' $t$ ' $=0.11)$ is less than the table value at 0.05 level of significance ( 2.01 at 0.05 level of significance ). Therefore, the result is not significant and it indicates that there is no significant difference between Science Male and Science Female Teachers regarding their attitude towards the Right to Education Act (2009). Hence, the null hypothesis is accepted.

$\mathrm{HO}_{8}$ : There is no significant difference between Arts Male and Science Male Teachers regarding their attitude towards the Right to Education Act (2009).

Table no-9

Shows the difference between Arts Male and Science Male Teachers regarding their attitude towards the Right to Education Act (2009)

\begin{tabular}{|c|c|c|c|c|c|c|c|c|}
\hline Groups & N & Mean & S.D & Mean Difference & SED & df & $\begin{array}{c}\text { t-value } \\
\text { Significance }\end{array}$ \\
\hline Arts Male Teachers & 66 & 145.53 & 13.83 & & 0.91 & 2.67 & 109 & 0.34 \\
$\begin{array}{c}\text { Science Male } \\
\text { Teachers }\end{array}$ & 45 & 146.44 & 13.89 & Not Significant \\
\hline
\end{tabular}

From the table no-9, it is observed that the calculated ' $t$ '-value (' $t$ ' $=0.34$ ) is less than the table value at 0.05 level of significance (1.98 at 0.05 level of significance). Therefore, the result is not significant and it indicates that there is no significant difference between Arts Male and Science Male Teachers regarding their attitude towards the Right to Education Act (2009). Hence, the null hypothesis is accepted.

H09: There is no significant difference between Arts Female and Science Female Teachers regarding their attitude towards the Right to Education Act (2009).

Table no-10

Shows the difference between Arts Female and Science Female Teachers regarding their attitude towards the Right to Education Act (2009)

\begin{tabular}{|c|c|c|c|c|c|c|c|c|}
\hline Groups & N & Mean & S.D & $\begin{array}{c}\text { Mean } \\
\text { Difference }\end{array}$ & S $_{\text {ED }}$ & df & t-value & $\begin{array}{c}\text { Level of } \\
\text { Significance }\end{array}$ \\
\cline { 1 - 4 } Arts Female Teachers & 24 & 150.29 & 17.56 & 4.36 & 5.25 & 37 & 0.83 & Not Significant \\
\hline Science Female Teachers & 15 & 145.93 & 14.89 & & &
\end{tabular}

From the table no-10, it is observed that the calculated ' $t$ '-value (' $t$ ' $=0.83$ ) is less than the table value at 0.05 level of significance (2.03 at 0.05 level of significance). Therefore, the result is not significant and it indicates that there is no significant difference between Arts Female and Science Female Teachers regarding their attitude towards the Right to Education Act (2009). Hence, the null hypothesis is accepted.

\section{Major Findings of the Study}

1. It is found that the level of Attitude of Headmasters of the district of Purulia, West Bengal is at Moderate level towards the 'Right to Education Act, 2009'. It means that the level of Attitude of secondary school Headmasters of the district of Purulia, West Bengal is neither Favorable nor Unfavorable i.e. Moderate towards the Right to Education Act, 2009.

2. It is found that the Attitude of secondary school Teachers of the district of Purulia, West Bengal is at Favorable level. It means that the level of Attitude of secondary school Teachers of the district of Purulia, West Bengal is Favorable towards the 'Right to Education Act, 2009'.

3. It is found that there is significant difference between Headmasters and Teachers regarding their attitude towards the 'Right to Education Act, 2009'. And it means that the attitude of Teachers is more favorable than that of the Headmasters in the district of Purulia, West Bengal towards the 'Right to Education Act, 2009'.

4. It is found that there is no significant difference between the Male and Female Teachers regarding their attitude towards the 'Right to Education Act, 2009'. But on the basis of their obtained Mean Score, it can be said that the Female Teachers are possessed comparatively more favorable attitude than that of the Male Teachers towards the 'Right to Education Act, 2009'.

5. It is found that there is no significant difference between Arts and Science Teachers regarding their attitude towards the 'Right to Education Act, 2009'.

6. It is found that there is no significant difference between Arts Male and Arts Female Teachers regarding their attitude towards the 'Right to Education Act, 2009'. But on the basis of their obtained Mean Score, it 
can be said that the Arts Female Teachers are possessed comparatively more favorable attitude than that of the Arts Male Teachers towards the 'Right to Education Act, 2009'.

7. It is found that there is no significant difference between Science Male and Science Female Teachers regarding their attitude towards the 'Right to Education Act, 2009'.

8. It is found that there is no significant difference between Arts Male and Science Male Teachers regarding their attitude towards the 'Right to Education Act, 2009'.

9. It is found that there is no significant difference between Arts Female and Science Female Teachers regarding their attitude towards the 'Right to Education Act, 2009'. But on the basis of their obtained Mean Score, it can be said that the Arts Female Teachers are possessed comparatively more favorable attitude than that of the Science Female Teachers towards the 'Right to Education Act, 2009'.

\section{Conclusion}

The 'Right to Education Act (RTE Act)' passed by the Indian Government in 2009, is undoubtedly a significant landmark in the history of Indian Education System. This Act made revolutionary changes in the traditional system by making the education upto 14 years of age for every child as a fundamental right in India. This Act has imposed so many vital role and responsibilities upon the Government both Central and State, parents or guardians, teachers and after all the Head of the Institution or Headmasters. Due to this Act, the role of the teachers especially of the Headmasters is extended too wide in every field like, admission, retention, examination and completion of elementary education by the every child upto 14 years of age. But few aspects of this Act are very difficult to implement in real situation by the Headmasters. That's why it is found through the present study that the secondary school Headmasters are not favorable about the all aspects related to elementary education enshrined in the RTE Act (2009). But to compare with that the secondary school Teachers are more favorable about the various aspects related to elementary education enshrined in the RTE Act (2009).

\section{References:}

[1]. Best, J.W. (1977). Research in Education, Eaglewood Cliffs, New Jersey, Prentice Hall.

[2]. Census of India Report (2011): Registrar General Census Commission of India.

[3]. Dey, Niradhar., \& Beck, Binod. (2011). The Right of Children to Free and Compulsory Education Act 2009: Teachers Perception. Journal of Educational Research (EDUSEARCH). Vol.2, Number-2, 83-90.

[4]. Gadam, Ajay. M. (2013). Teacher Awareness of the Responsibility under Right to Free and Compulsory Education Act. International Indexed \& Refereed Journal. Vol. 5, Issue. 49, 38-40.

[5]. Human Development Report (2014). United Nations Development Programme, One United Nations Plaza, New York, NY 10017

[6]. Jaseena, Fathima. (2011). Right to Education - A Study on the Awareness of M.Ed Trainees. Journal of Educational Research (EDUSEARCH). Vol.2, Number-2, 63-66.

[7]. Kumar, Dinesh. \& Sharma, Sarita. (2011). A Study of Parents and Teachers Awareness towards Right to Education Act 2009. Journal of Educational Research (EDUSEARCH). Vol.2, Number-2, 129-132.

[8]. Malik, Sarika., Serohi, Seema., and Tayal, Ajay. (2013). Awareness of Right to Education Act among Prospective Teachers. Research journali's Journal of Education. Vol. 1, No. 2, 1-6.

[9]. Panda, B. K. (2011). Lifelong Learning - the Japanese Experience: Implications for India and the Medium and Lowly Developed Countries. Journal of Educational Research (EDUSEARCH). Vol.2, Number-2, 7-15.

[10]. Premlakshmi, K. (2011). Right to Education and Common School System-Perception among Teachers. Journal of Educational Research (EDUSEARCH). Vol.2, Number-2, 106-111.

[11]. Right to Education Act (2009): Department of Elementary Education and Literacy, MHRD, Government of India, New Delhi. 